UDC $615.242: 454.1: 011$

DOI: $10.15587 / 2519-4852.2019 .182398$

\title{
STUDY OF STRUCTURAL AND MECHANICAL PROPERTIES OF BASES IN THE DEVELOPMENT OF DENTAL GEL WITH COMBINED COMPOSITION
}

\author{
D. Orlenko, V.Yakovenko, L.Vyshnevska
}

\begin{abstract}
Мета. Розробка складу стоматологічного гелю для лікування інфекційно-запальних захворювань порожнини роту з урахуванням фізико-хімічних властивостей активних фармацевтичних інгредієнтів, а саме обтрунтування виду та концентрації гелеутворювача та інших допоміжних речовин.

Методи. Визначення органолептичних характеристик, однорідності зразків гелю, рН водного витягу, показника структурної в'язкості проводили за методиками Державної фармакопеї Украӥни. Реологічні дослідження проводили за допомогою ротаційного віскозиметра обертового типу BROOKFIELD DVII+PRO (США) з системою коаксіальних ичиліндрів.

Результати. 3 метою вибору оптимального складу гелевої основи були напраџьовані експериментальні зразки з різними гелеутворювачами (Carbopol ${ }^{\circledR} 974$, Carbopol $^{\circledR}$ 934P, Carbopol® Ultrez 10, ксантанова камідь, натрію альгінат, натрію кармелоза) та досліджено їх органолептичні характеристики, структурну в'язкість та колоїдну стабільність. Проведені фізико-хімічні та реологічні дослідження дозволяють зробити висновок про ращіональність використання гелеутворювача карбополу марки Ultrez 10 в концентрації 1,1\%. При виборі нейтралізуючих агентів в дослідженнях використовували натрію гідроксид і трометамол. За результатами досліджень в якості нейтралізатора був обраний натрію гідроксид в концентрації 0,32 \%, який забезпечує максимальну, стабільну в'язкість в інтервалі рН від 5,0 до 7,0.

Висновки. Розроблено склад основи стоматологічного гелю для лікування інфекційно-запальних захворювань порожнини роту: карбопол марки Ultrez 10-1,1\%, розчин натрію гідрооксиду 10\%-0,32\%
\end{abstract}

Ключові слова: гель, гелеутворювач, карбомери, реологія, в'язкість, стоматологічний лікарський засіб

Copyright (C) 2019 O. D. Orlenko, V.Yakovenko, L.Vyshnevska This is an open access article under the CC BY license (http://creativecommons.org/licenses/by/4.0).

\section{Introduction}

Oral disease and mucosal lesions are among the most common medical problems [1]. Anaerobic microorganisms (such as P. intermedia) play a major role in the development of gingivitis and periodontitis, most notably bacteria that produce aggressive enzymes that destroy connective tissue proteins and bone tissue. It was found that in the microbial flora of the oral cavity of a healthy person, the bacteroides are practically absent - their number is $1.0-2.5 \%$ [2-4].

Taking into account the above information, during the design of a complex drug it is necessary to choose an active pharmaceutical ingredient (API) that will exhibit, first of all, antibacterial action. Usually the best result has a combination of several antimicrobial agents [5]. That is why we have chosen metronidazole and miramistin to provide a broad spectrum of antibacterial effect as active substances for the developed product. The choice of dosage form is essential to ensure the effectiveness of pharmacotherapy of various diseases, in particular, are well recommended in the provision of dental care the use of prolonged dosage forms of application in the form of gels [6].

When creating a gel formulation, a whole set of excipients is used, which ensures the physical, chemical and microbiological stability of the product over a period. For rational pharmacotherapy, it is very important to use adjuvants optimally, as their share is constantly increasing today.
According to the definition given in the general article "Soft drugs for skin use" by SPhU [7] and the general article "Semi-solid preparations for cutaneous application" by the European Pharmacopoeia [8], gels are a dosage form consisting of liquids, in which gelation is achieved using suitable gel-forming agents. Hydrophilic gels (hydrogels) are medicines that are usually based on water, glycerol or propylene glycol and such gelling agents as poloxamers, starch, cellulose derivatives, carbomers and magnesium aluminium silicates $[7,8]$.

Among the dosage forms for external use in the treatment of various dental diseases, the most commonly used are drugs in the form of gel [9]. Gels provide a local action and smooth release of the active substance from the base, which create their high therapeutic concentration directly in the application area, without significantly increasing the level of the active substance in the systemic circulation. Often, for dental gels, copolymers of acrylic acid, namely carbomers, are used as gel-forming agents [10-12].

Carbomers in the composition of gels can perform a variety of functional purposes. They can be modifiers of rheological properties and stabilizers of heterogeneous dispersion systems (emulsions, suspensions), can provide controlled release of drugs and bioadhesion of gels to the skin and mucous membranes, which may affect the bioavailability and effectiveness of the specific action of drugs [13]. 
Systematic studies were conducted by N. V. Volovik [14] on the effect of carbomer concentration, the chemical nature of alkali, $\mathrm{pH}$ of gels, temperature, and a number of other factors on the rheological properties of gels based on carbomers 934P, 940, 980, and 971P. The structural viscosity of gels with carbomers increases with their content and molecular weight depends on the nature of the alkali, passes through the maximum depending on the $\mathrm{pH}$ of the gels and hardly changes with temperature $[14,15]$. Thus, the development of a gel with a new combination of active ingredients requires the study of the above factors.

A negative factor in gel technology is the period required to wet and swell for the widely used 934P, 940, and 980 carbomers, as well as the risk of mechanical inclusions ("fisheye") that occur after neutralizing carbomer dispersions. In this regard, Lubrizol has introduced a number of advanced carbohydrates with a property of rapid self-wetting within minutes without any stirring. These carbomers are commercially available under the trade names Carbopol ${ }^{\circledR}$ Ultrez 10 [16], Carbopol ${ }^{\circledR}$ Ultrez 21 [17], and have been used in our studies.

The basis of the dental gel should provide a reliable application of the drug on the gums and increase the permeability of the active substances. Structural-mechanical studies are known to be mandatory for the development of any soft drug (ointment, cream, gel) [18, 19].

Structural-mechanical properties have a significant influence on the processes of release and penetration of drugs from soft dosage forms, as well as on their consumption properties: lubricity, adhesion, ability to squeeze out of the tube. That is why determining and evaluating rheological characteristics is an important and integral part of research during the design of soft dosage forms [20-22].

The aim of the study was to develop the composition of a dental gel, taking into account the physicochemical properties of active pharmaceutical ingredients, namely, the justification of the type and concentration of the gel and other excipients. The objectives of the research were to determine the structural and mechanical properties of the gels, to determine the optimal concentrations of the gel and the neutralizer, to study the stability of model samples of gels.

\section{Planning (methodology) of research}

Part of module 3 of the CTD registration dossier is pharmaceutical development, which begins with the study of the components of the medicinal product, including excipients, the study of the physico-chemical properties of the drug. In the development of soft dosage forms for determining structural and mechanical parameters, studies of the mechanical and colloidal stability of gels allow you to make a reasonable choice of the basis, to determine the optimal concentrations of the gel, the neutralizer and other auxiliaries. The choice of gel base is one of the critical factors of quality, which affects the technological, consumer, therapeutic characteristics of the medicinal product.

\section{Materials and methods}

The objects of rheological studies were gels of high molecular weight compounds and gels formed by the neutralization of carbomers with sodium hydroxide or tromethamine. As the active substances in the composition of the gels were introduced metronidazole benzoate, miramistin, hyaluronic acid $[8,23]$.

Excipients with the following functional purpose were used in the experiment: gel-forming agents: Carbopol ${ }^{\circledR} 974 \mathrm{P}$, Carbopol ${ }^{\circledR}$ 934P $[8,23]$, Carbopol ${ }^{\circledR}$ Ultrez 10 [16], xanthan gum, sodium alginate [8], carmellose sodium [8]; $\mathrm{pH}$ neutralizers and regulators: sodium hydroxide and tromethamine [7]; solvents (propylene glycol (PG), purified water) [7].

The determination of the homogeneity of the gel samples made by the above technology was performed according to the method of SPhU 1.1, p. 511. The determination of organoleptic characteristics was carried out according to SPhU 2.0, the $\mathrm{pH}$ of the aqueous extract according to the method in SPhU 1.2, 2.2.3, p. 46.

Determination of colloidal stability. The tubes were filled with $2 / 3$ of the volume (approximately 9.0 g) of the test samples (so that the masses of the test tubes with the drug did not differ more than $0.02 \mathrm{~g}$ ), and weighed accurately up to $0.01 \mathrm{~g}$. The tubes were then placed in a water bath at $(42.5 \pm 2.5){ }^{\circ} \mathrm{C}$ for $20 \mathrm{~min}$, then wiped dry and placed in centrifuge wells. Centrifuged for $5 \mathrm{~min}$ at a speed of $6000 \mathrm{rpm}$. Stability was determined visually - in the absence of separation.

Structural viscosity $\eta\left(\mathrm{mPa}^{*} \mathrm{~s}\right)$ was determined by SPhU 2.0, volume 1, section 2.2.8. Measurement of shear stress $\tau\left(\mathrm{Pa}\right.$ or $\left.\mathrm{N} / \mathrm{m}^{2}\right)$ and shear rate $\operatorname{Dr}\left(\mathrm{c}^{-1}\right)$ was performed by increasing the spindle speed from 20 to $100 \mathrm{rpm}$, reaching constant values at maximum rotation and further reducing the spindle rotation speed. Samples were investigated using a BROOKFIELD DV-II + PRO (USA) rotary viscometer with coaxial cylinder system. The prepared $8 \mathrm{ml}$ samples were introduced into a special chamber in an adapter connected to the Brookfield DV-II-Pro Water Circulation viscometer. SC4-21 spindle was used to measure the performance.

The mechanical stability of the gel samples was defined as the ratio of the value of the tensile strength of the structure to fracture $\left(\tau_{1}\right)$ to the value of the tensile strength after fracture $\left(\tau_{2}\right): \mathrm{MC}=\tau_{1} / \tau_{2}$,

\section{Results}

According to our previous studies, it was found that the selected active substances are well soluble in water or hydrophilic solvents, but the solubility of individual API is strongly influenced by the temperature factor [24]. Thus, it was rational for the preparation of dental gel to use hydrophilic gel formers. These bases have high mucoadhesiveness, which is the ability to retain on the mucous membrane, facilitating the localization of the action of the active components of the drug on the one hand, and the prolongation of their pharmacological effect - on the other.

According to the literature, synthetic high molecular weight polymers of acrylic acid - carbomers are most widely used in the world pharmaceutical practice for the production of gels $[13,19]$. During the experimental selection of the gel-forming agent, other gel-forming agents were also studied: carmellose sodium, sodium alginate, xanthan gum. 
When choosing a gel-forming agent that would provide both optimal physico-chemical characteristics of the gel and the most optimal way of introducing the gel production process, the swelling ability of the gelforming carbomers was studied: Carbopol ${ }^{\circledR} 974 \mathrm{P}$, Carbopol ${ }^{\circledR}$ 934P, Carbopol ${ }^{\circledR}$ Ultrez 10. According to the results of our experiments, we found that the rate of attainment of the maximum degree of swelling of Carbopol ${ }^{\circledR}$ Ultrez 10 repeatedly exceeded the rate of swelling of the other two brands of carbomers.

Experimental samples with different gel-forming agents were studied to determine the optimal composition of the gel base and their structural viscosity and colloidal stability were investigated. Due to the physicochemical properties and nature of the origin of the selected gel formers, the mechanism of gel formation experimental samples were prepared as follows: macromolecu- lar compounds (carmellose sodium, xanthan gum, sodium alginate) was poured into the calculated amount of purified water, left for a certain time to swell, then dissolved, stirred with heating or at room temperature.

Samples of gels with different brands of carbopol were prepared by standard technology: the required amount of carbopol was added to purified water and left for swelling of the carbopol for a certain time. After stirring, the selected neutralizer was added and stirring was continued until a homogeneous consistency gel was formed.

API solutions were added to each of the experimental samples, and homogenization was performed.

The obtained samples were analyzed for organoleptic and physical characteristics, investigated their colloidal stability. The results are presented in Table 1 .

Table 1

\begin{tabular}{|c|c|c|c|c|c|c|}
\hline \multicolumn{7}{|c|}{ Organoleptic characteristics of experimental gel samples } \\
\hline \multirow[b]{2}{*}{ Characteristic } & \multicolumn{6}{|c|}{ Experimental gel samples based on different gel formers } \\
\hline & $\begin{array}{l}\text { Carbopol } \\
\text { Ultrez } 10\end{array}$ & Carbopol $974 \mathrm{P}$ & Carbopol $934 \mathrm{P}$ & $\begin{array}{l}\text { Carmellose } \\
\text { sodium } 5 \%\end{array}$ & $\begin{array}{c}\text { Sodium algi- } \\
\text { nate } 2 \%\end{array}$ & $\begin{array}{c}\text { Xanthan gum } \\
1 \%\end{array}$ \\
\hline Appearance & $\begin{array}{l}\text { Gel of uniform } \\
\text { consistency } \\
\text { and white } \\
\text { colour }\end{array}$ & $\begin{array}{c}\text { Gel of uniform } \\
\text { consistency and } \\
\text { white colour }\end{array}$ & $\begin{array}{l}\text { Gel of uniform } \\
\text { consistency and } \\
\text { white colour }\end{array}$ & $\begin{array}{c}\text { Gel of uniform } \\
\text { consistency and } \\
\text { white colour }\end{array}$ & $\begin{array}{l}\text { Gel of homoge- } \\
\text { neous, semi- } \\
\text { liquid consisten- } \\
\text { cy and light } \\
\text { yellow colour }\end{array}$ & $\begin{array}{c}\text { Gel of uniform } \\
\text { consistency of } \\
\text { light yellow } \\
\text { colour }\end{array}$ \\
\hline $\begin{array}{l}\mathrm{pH} \text { of } 10 \% \\
\text { solution }\end{array}$ & 5.92 & 6.58 & 6.23 & 7.81 & 6.85 & 7.67 \\
\hline $\begin{array}{l}\text { Structural vis- } \\
\text { cosity, } \\
\eta(\mathrm{MPa} \bullet \mathrm{s})\end{array}$ & 3650 & 3380 & 2820 & 2500 & 1230 & 2900 \\
\hline $\begin{array}{c}\text { Colloidal stabil- } \\
\text { ity } \\
\text { (at } 5000 \mathrm{rpm} \text { ) }\end{array}$ & Stable & Stable & Stable & Unstable & Unstable & Stable \\
\hline
\end{tabular}

According to Table 1, it can be concluded that all the experimental samples had a homogeneous consisten$\mathrm{cy}$, the $\mathrm{pH}$ of all gel samples close to neutral, the structural viscosity characterizing the obtained gels as plastic systems except for the sodium alginate gel. According to the colloidal stability test, the samples based on carmellose sodium and alginate sodium are not stable.

Investigation of the structural-mechanical characteristics of the experimental gel samples was performed on a BROOKFIELD DV-II + PRO rotary viscometer with a coaxial cylinder system. The results of the studies are presented as graphs in Fig. 1.

Based on the data in Fig. 1, the structural viscosity of the experimental samples gradually decreases with increasing shear rate. This dependence is characteristic of systems with a plastic type of flow and characterizes their ability to thin, easily apply and distribute on the skin and mucous membranes.
In addition, the graphs in Fig. 1 show that carbomers as a base dominated other types of bases, and the experimental sample of gel with Carbopol ${ }^{\circledR}$ Ultrez 10 has the highest viscosity at the same concentrations of carbomers.

Thus, according to the results of gel research, Carbopol® Ultrez 10 was selected for our dental gel because it has the best rheological parameters, the highest rate of swelling, and the simple technology of gel formation.

The next step was to determine the optimal concentration, namely Carbopol ${ }^{\circledR}$ Ultrez 10 , which should provide balanced organoleptic, technological and consumer properties of the gel. Samples of gel with a concentration of carbopol from $0.7 \%$ to $1.5 \%$ were made and their homogeneity, lubricity, structural and mechanical parameters were studied. The results are shown in Table 2. 


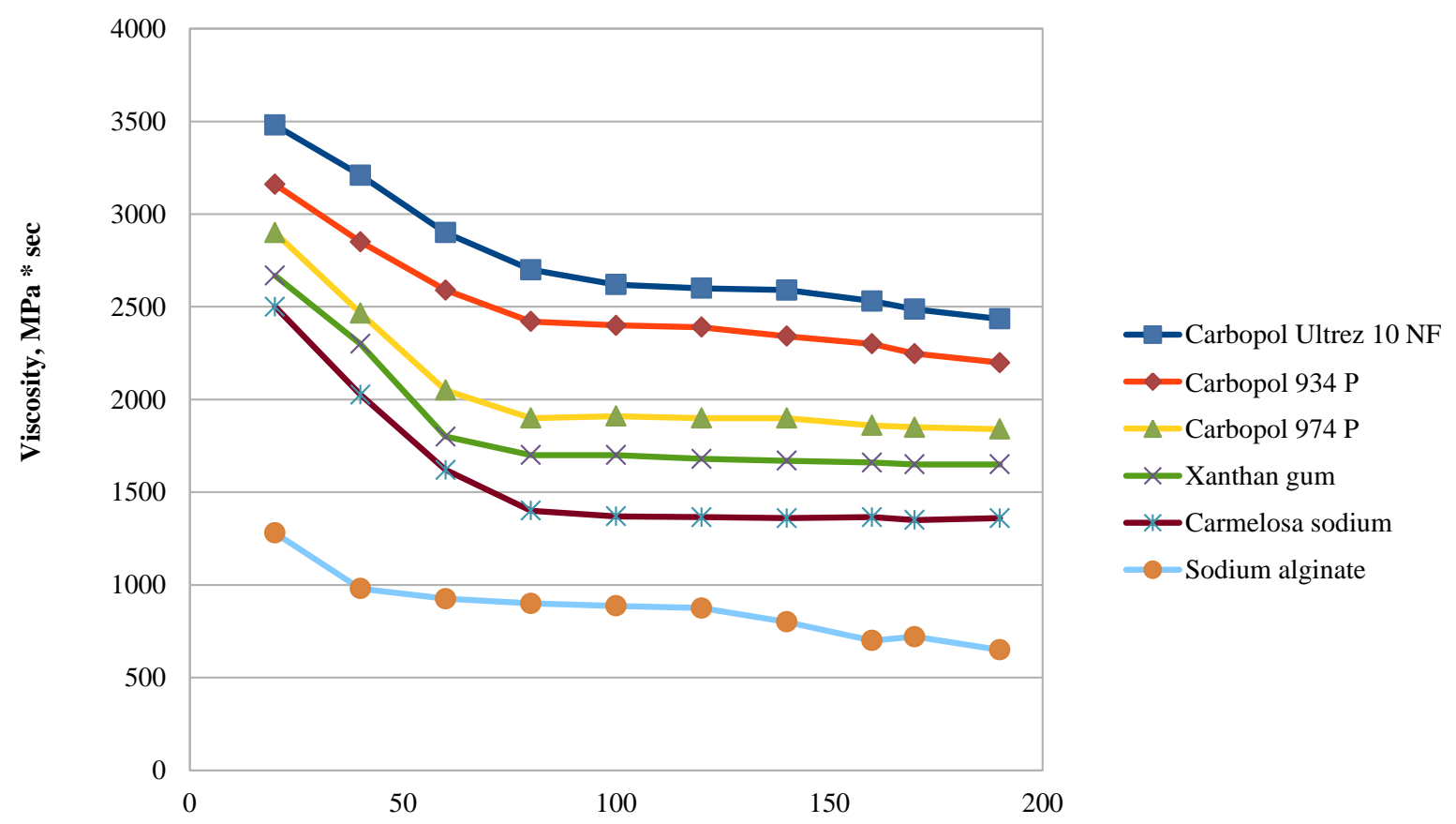

Shear rate, $1 / \mathrm{s}$

Fig. 1.The dependence of the structural viscosity of the gel samples on the shear rate

Physico-chemical characteristics of gel compositions based on Carbopol ${ }^{\circledR}$ Ultrez 10

\begin{tabular}{|c|c|c|c|c|c|}
\hline $\begin{array}{c}\text { No. of } \\
\text { sample }\end{array}$ & $\begin{array}{c}\text { Carbopol con- } \\
\text { centration, } \%\end{array}$ & The appearance of the gel & Homogeneity & Spreadability & $\begin{array}{c}\text { Structural } \\
\text { viscosity, } \eta\end{array}$ \\
\hline 1. & 0.7 & $\begin{array}{c}\text { Translucent, white, semi- } \\
\text { liquid consistency }\end{array}$ & homogeneous & +- & 2520 \\
\hline 2. & 0.9 & $\begin{array}{c}\text { Translucent, white, low } \\
\text { viscous consistency }\end{array}$ & homogeneous & ++ & 3110 \\
\hline 3. & 1.1 & $\begin{array}{c}\text { Translucent, white, viscous } \\
\text { consistency }\end{array}$ & homogeneous & ++ & 3550 \\
\hline 4. & 1.5 & $\begin{array}{c}\text { Translucent, white, viscous } \\
\text { consistency }\end{array}$ & homogeneous & + & 3770 \\
\hline 5. & Translucent, white, dense \\
consistency & homogeneous & - & 4490 \\
\hline
\end{tabular}

Based on the technological performance of the various gel compositions shown in Tab. 2, in the further studies the compositions № 2, 3, 4 were used.

The next step was to study the rheological characteristics of the selected experimental specimens' No. 2, 3, 4. The studies were carried out at room temperature using a SC4-21 spindle.

The rheological parameters of the samples are shown in Fig. 2.

Conducted physico-chemical and rheological studies allowed to conclude on the rational use of gelforming carbopolUltrez 10 at a concentration of $1.1 \%$.

The study of the $\mathrm{pH}$ of the gel is an important factor not only in terms of the stability of the gel structure, but also provides chemical stabilization of hyaluronic acid in the preparation.
Sodium hydroxide and v were used as neutralizing agents in the studies. As a result of the studies, sodium hydroxide was selected as the alkaline agent. Sodium hydroxide also acts as a $\mathrm{pH}$ correcting agent for the gel. The $\mathrm{pH}$ of the dental gel for the treatment of infectious inflammatory diseases of the gums and mucous membrane of the mouth is normalized within the range of 5.0 to 7.0.

The viscosity of the carbopol gel depends on the $\mathrm{pH}$ value. In the course of the experiment, the dependence of the gel viscosity on the $\mathrm{pH}$ value, in this case, of the amount of sodium hydroxide introduced was studied. The viscosity was determined on a Brookfield II + viscometer using disk spindles at a speed of $20 \mathrm{rpm}$. The research data are presented in Fig. 3. 


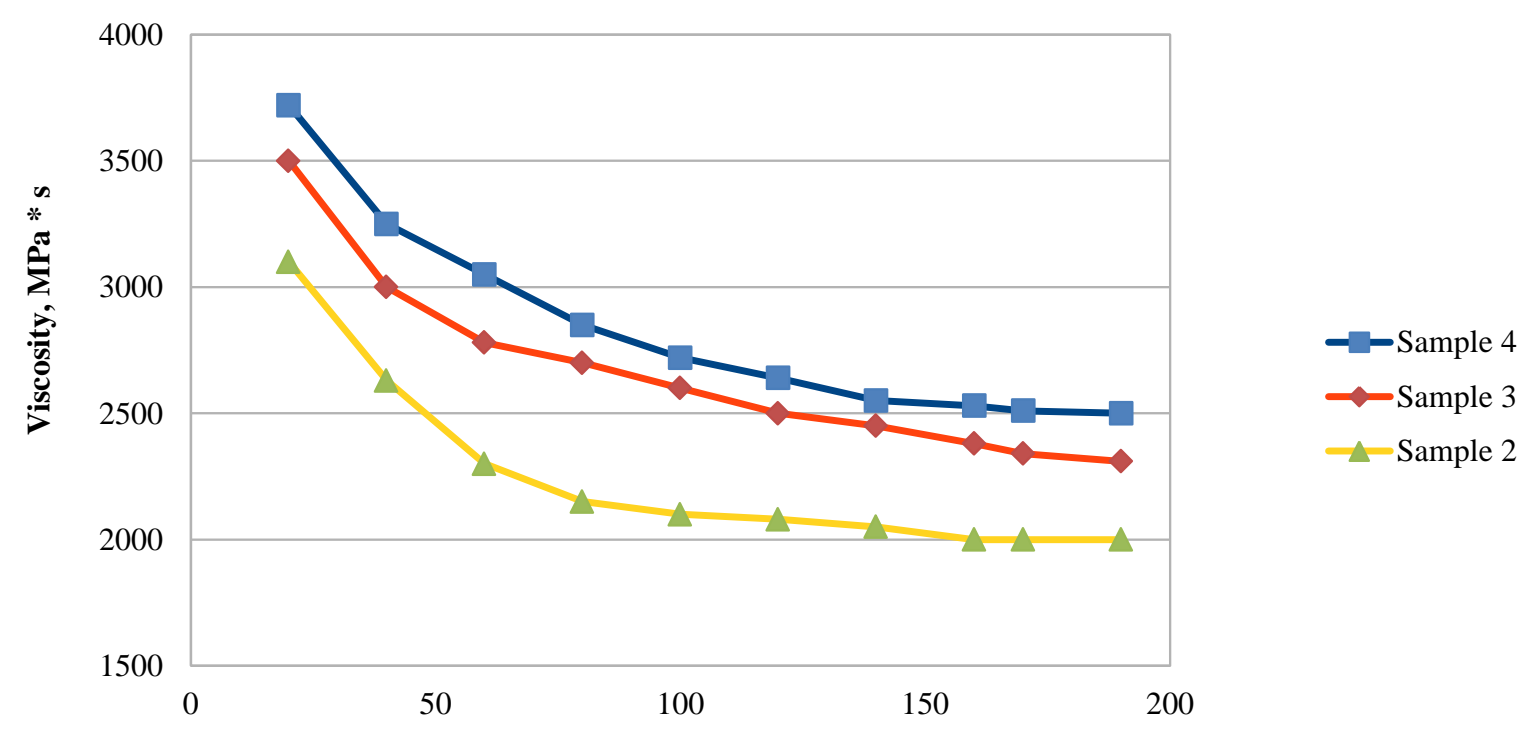

Shear rate, $1 / \mathrm{s}$

Fig. 2. Dependence of structural viscosity of Carbopol® Ultrez 10 based gel samples on shear rate

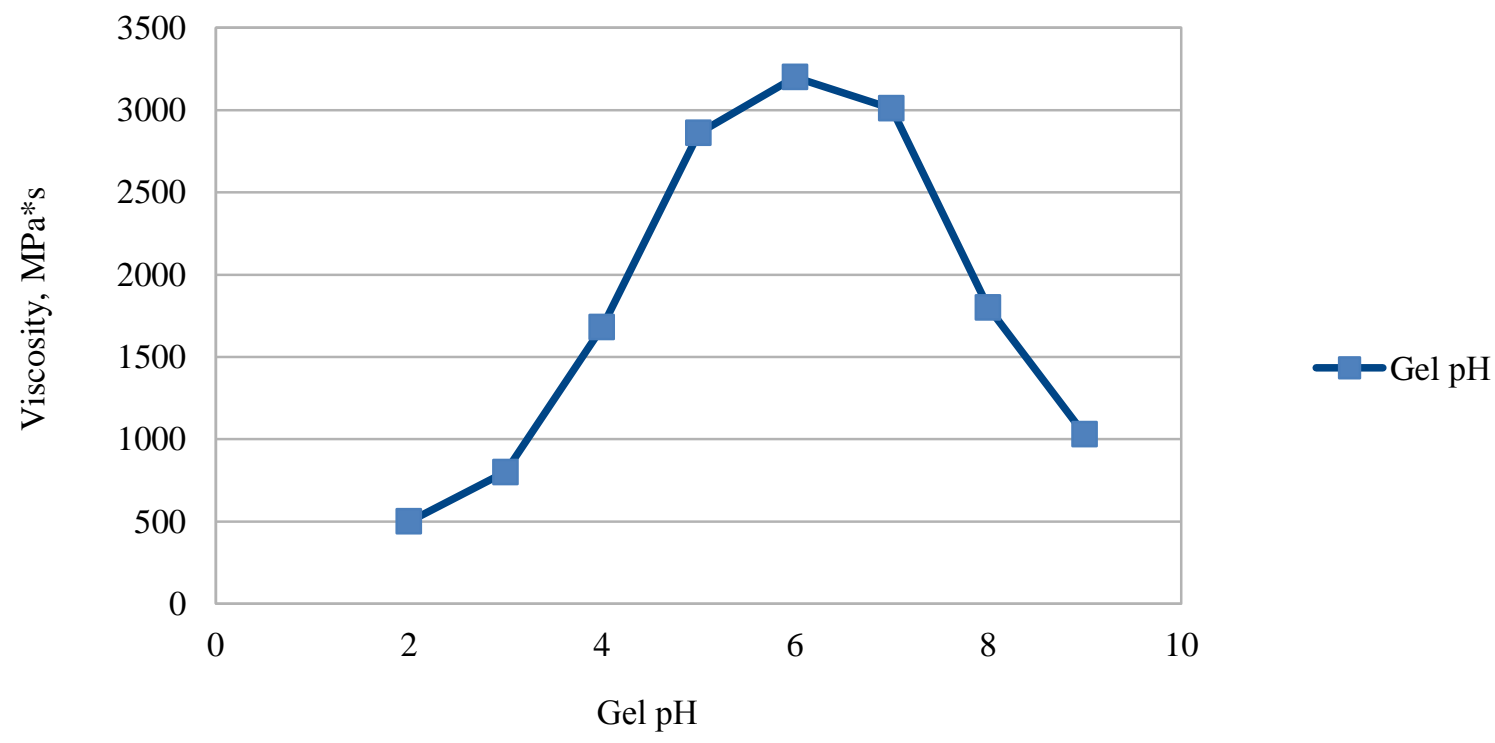

Fig. 3. Dependence of gel viscosity on $\mathrm{pH}$ value

As can be seen from Fig. 3, maximum, stable viscosity was achieved in the $\mathrm{pH}$ range from 5.0 to 7.0 .

The sodium hydroxide concentration was selected by varying the percentage of ingredients in a quantitative ratio.

Samples with different content of carbopol with the introduction of different concentrations of sodium hydroxide were analyzed. The obtained data were presented in Table 3.

We selected a sodium hydroxide concentration at which the $\mathrm{pH}$ of the gel was closest to the middle of the selected $\mathrm{pH}$ range $(\mathrm{pH}=6.0)$. The sodium hydroxide concentration was $0.32 \%$. Fig. 4 shows a diagram of the resulting gel.

Table 3

The dependence of the $\mathrm{pH}$ of the gels on the concentration of sodium hydroxide

\begin{tabular}{|c|c|c|}
\hline No. & The concentration of sodium hydroxide, $\mathrm{mg} / \mathrm{g}$ & $\mathrm{Gel} \mathrm{pH}$ \\
\hline 1 & 1.00 & 3.50 \\
\hline 2 & 2.00 & 4.80 \\
\hline 3 & 2.90 & 5.40 \\
\hline 4 & 3.20 & 6.00 \\
\hline 5 & 3.50 & 7.20 \\
\hline
\end{tabular}




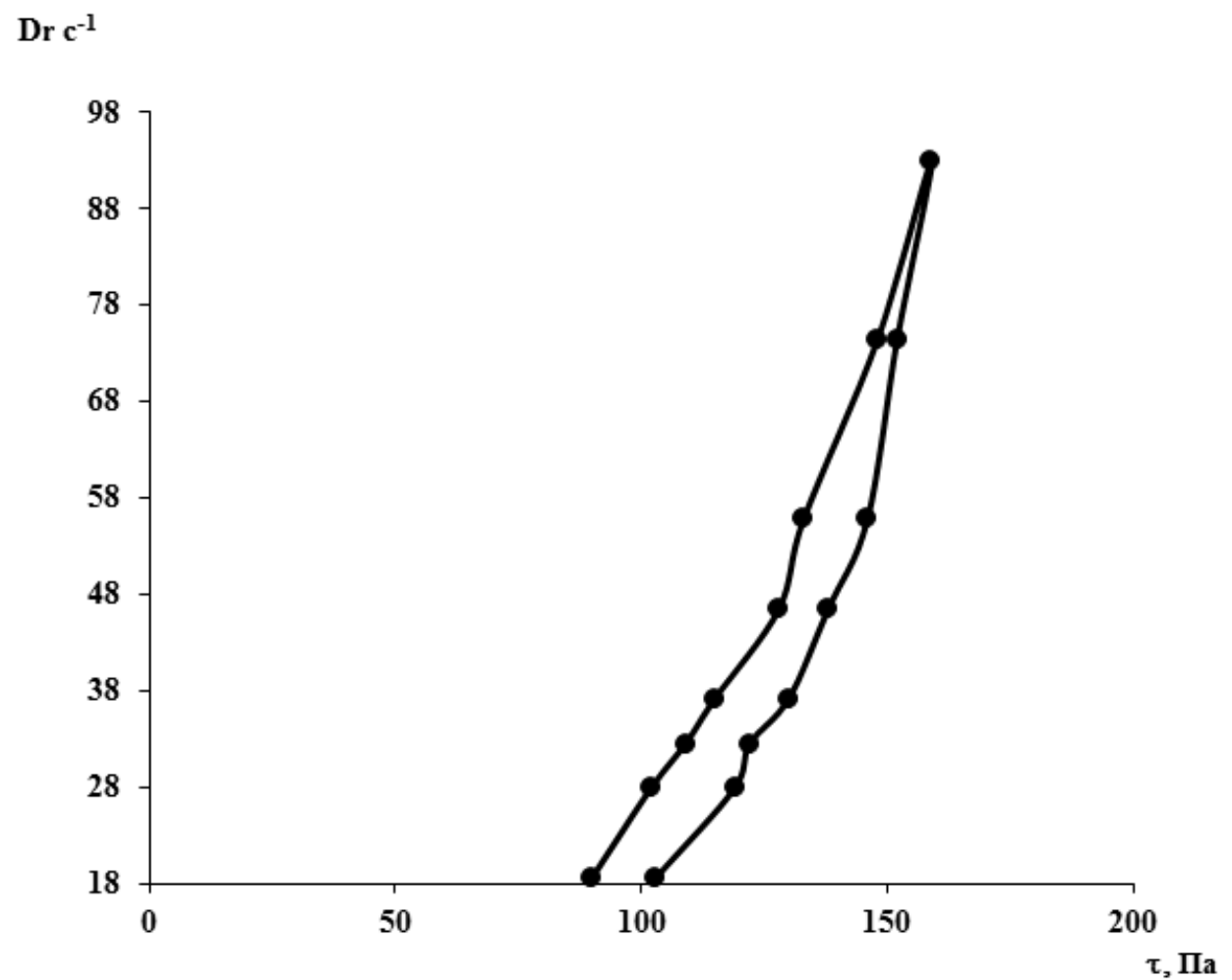

Fig. 4. Gel rheogram containing $1.1 \%$ Carbopol® Ultrez 10, neutralized with sodium hydroxide to $\mathrm{pH}(6.0 \pm 0.2)$

As can be seen from the diagram, the obtained dependence is nonlinear. The resulting gel is a nonNewtonian fluid with a plastic flow type. The fluidity of the sample begins after the application of low voltage, which is due to the need to break the elements of the structure.

The calculated value of the mechanical stability of the resulting gel, close to the optimum - 1.06, which indicates a small degree of destruction of the structural skeleton of the gel and allows the system to recover due to the presence of coagulation bonds. The restoration of the structure is important and indicates the ability to withstand mechanical action in the process of mixing and homogenization of the gel, as well as ensure stability during long-term storage of the drug.

\section{Discussion}

The results of the studies confirmed the superiority of synthetic gel formers (carbopol) over high molecular weight compounds. Carbomer based gels are stable and have better structural and mechanical characteristics. We have also seen that the introduction into the gel base of active substances (metronidazole benzoate, myramistine, hyaluronic acid) has no significant effect on rheological parameters. The use of sodium hydroxide as a neutralizer provides high levels of structural viscosity within the physiological mouth $\mathrm{pH}$. Selected as the basis Carbopol Ultrez 10 is the most technological gel-forming agent, which in a sufficiently low concentration of $1.1 \%$ provides satisfactory rheological parameters and consumption characteristics of the dental gel.

Further development of the gel composition may require repeated (comparative) study of structural and mechanical parameters after the introduction of chemical stabilizers, preservatives and other types of auxiliaries into the base. Rheological studies are the first stage in the development of a gel composition and should be supplemented by biopharmaceutical studies to confirm the release of active substances from the base and their penetration into the tissues.

\section{Conclusions}

Structural-mechanical characteristics of gels with combined composition based on carbopols and macromolecular compounds of semi-synthetic and natural origin were studied. It was determined that gels based on Carbopol ${ }^{\circledR}$ Ultrez 10 are more preferable in physicochemical, technological and consumer properties.

The rational concentration of Carbopol ${ }^{\circledR}$ Ultrez 10 gel-forming agent was found to be $1.1 \%$. Sodium hydroxide solution at a concentration of $0.32 \%$ used as a neutralizer, provides a stable $\mathrm{pH}$ value of the developed dental gel.

Rheological studies have proven that Carbomer U1trez 10 gel is a plastic system with moderate thixotropic properties and satisfactory consumer characteristics.

\section{References}

1. Artiushkevich, A. S. (2006). Zabolevaniia periodonta. Moscow: Medicinskaia literatura, 306.

2. Lukianchuk, V. D., Hordiichuk, D. O. (2015). Suchasnyi stan pytannia patohenezu parodontytu ta yoho farmakokorektsii (ohliad literatury). Medytsyna sohodni i zavtra, 2 (67), 14-22.

3. Kingman, A., Albandar, J. M. (2002). Methodological aspects of epidemiological studies of periodontal diseases. Periodontology 2000, 29 (1), 11-30. doi: http://doi.org/10.1034/j.1600-0757.2002.290102.x 
4. Tüzüner, T., Ulusoy, A. T., Baygin, O., Yahyaoglu, G., Yalcin, I., Buruk, K., Nicholson, J. (2013). Direct and Transdentinal (Indirect) Antibacterial Activity of Commercially Available Dental Gel Formulations againstStreptococcus mutans. Medical Principles and Practice, 22 (4), 397-401. doi: http://doi.org/10.1159/000347234

5. Vynohradova, O. M. (2013). Vykorystannia suchasnykh antymikrobnykh i protyzapalnykh preparativ mistsevoi dii v likuvanni zapalnykh zakhvoriuvan parodontu. Zdobutky klinichnoi i eksperymentalnoi medytsyny, 2, 47-49.

6. Mazur, I. P., Peredrii, V. A., Dulko, S. V. (2010). Farmakolohichni zasoby dlia mistsevoho likuvannia tkanyn parodontu. Sovremennaia stomatolohyia, $5,47-52$.

7. Derzhavna farmakopeia Ukrainy. Vol. 2 (2014). Kharkiv: Derzhavne pidpryiemstvo «Naukovo-ekspertnyi farmakopeinyi tsentr yakosti likarskykh zasobiv», 724 .

8. European Pharmacopoeia (2016). EDQM. Strasbourg: Council of Europe, 4016.

9. Rescala, B., Rosalem, W., Teles, R. P., Fischer, R. G., Haffajee, A. D., Socransky, S. S. et. al. (2010). Immunologic and Microbiologic Profiles of Chronic and Aggressive Periodontitis Subjects. Journal of Periodontology, 81 (9), 1308-1316. doi: http://doi.org/10.1902/jop.2010.090643

10. Davtian, L. L. (2006). Naukovo-praktychne obgruntuvannia tekhnolohii miakykh likarskykh form dlia stomatolohii. Kyiv, 304.

11. Ofner, C. M., Klech-Gelotte, C. M.; Swarbrick, J., Boylan, J. C. (Eds.) (2002). Gels and jellies. Encyclopedia of Pharmaceutical Tehnology. Vol. 2. NewYork: Basel: MarselDekker, 1327-1344.

12. Rahman, M. N. A., Qader, O. A. J. A., Sukmasari, S., Ismail, A. F., Doolaanea, A. A. (2017). Rheological Characterization of Different Gelling Polymers for Dental Gel Formulation. Journal of Pharmaceutical Sciences and Research, 9 (12), $2633-2640$.

13. Rowe, R. C., Sheskey, P. J., Cook, W. G., Fenton, M. E. (Eds.) (2012). Hand book of Pharmaceutical Excipients. London:Pharmaceutical Press, 1064.

14. Volovyk, N. V. (2008). Rozrobka i standartyzatsiia protyzapalnykh preparativ u formi heliv. Kharkiv, 20.

15. Islam, M. T., Rodríguez-Hornedo, N., Ciotti, S., Ackermann, C. (2004). Rheological Characterization of Topical Carbomer Gels Neutralized to Different pH. Pharmaceutical Research, 21 (7), 1192-1199. doi: http://doi.org/10.1023/ b:pham.0000033006.11619.07

16. Carbopol® Ultrez 10 Polymer (2002). Technical Data Sheet (TDS-225). Lubrizol: Cleveland

17. Carbopol ${ }^{\circledR}$ Ultrez 21 Polymer (2002). Technical Data Sheet (TDS-297). Lubrizol: Cleveland.

18. Malkin, A. IA., Isaev, A. I. (2007). Reologiia: koncepcii, metody, prilozheniia. Saint Petersburg: Professiia, 557. $11,25-27$

9. Aupova, R., Sakipova, Z., Zemlicka, M. (2014). Study of rheological properties of carbomer gels. Life Science Journal,

20. Gladukh, Ie. V., Grubnik, I. M., Kukhtenko, G. P., Stepanenko, S. V. (2015). Rheological studies of water-ethanol solutions of gel-formers. Journal of Chemical and Pharmaceutical Research, 7 (4), 729-734.

21. Davtian, L. L., Vashchuk, V. A., Polyshchuk, Yu. P. (2013). Reolohichni doslidzhennia yak osnova tekhnolohichnoho protsesu u razi stvorennia novoho likarskoho zasobu. Farmatsevtychnyi zhurnal, 4, 52-58.

22. Singh, V. K., Anis, A., Banerjee, I., Pramanik, K., Bhattacharya, M. K., Pal, K. (2014). Preparation and characterization of novel carbopol based bigels for topical delivery of metronidazole for the treatment of bacterial vaginosis. Materials Science and Engineering: C, 44, 151-158. doi: http://doi.org/10.1016/j.msec.2014.08.026

23. United States Pharmacopeia and National Formulary 2017 [USP 40 - NF35] (2016). Rockville: UnitedStatesPharmacopeialConvention, Inc, 7970.

24. Opredelenie sposoba vvedeniia v osnovu aktivnykh farmacevticheskikh ingredientov stomatologicheskogo gelia (2019). Aktualnye problemy sovremennoi mediciny i farmacii. Minsk, 1545.

Received date 27.08.2019

Accepted date 16.09.2019

Published date 31.10.2019

Volodymyr Yakovenko, Doctor of Pharmaceutical Sciences, Professor, Department of Industrial Pharmacy and Economics, National University of Pharmacy, Pushkinska str., 53, Kharkiv, Ukraine, 61002

Email: v.iakovenko@gmail.com

Dmytro Orlenko, Postgraduate Student, Department of Industrial Pharmacy and Economics, National University of Pharmacy, Pushkinska str., 53, Kharkiv, Ukraine, 61002

E-mail: dmitryorlenko@gmail.com

Liliia Vyshnevska, Doctor of Pharmaceutical Sciences, Professor, Department of Pharmacy Drug Technology, National University of Pharmacy, Pushkinska str., 53, Kharkiv, Ukraine, 61002

E-mail: liliiavyshnevska@gmail.com 